NOTE

\title{
Catalytic Hydrolysis of Charged Carboxylic Acid Active Esters with Cyclic Dipeptides Carrying Hydrophobic and Nucleophilic Groups
}

\author{
Koji KaWAGUCHI, Masao TANIHARA, and Yukio IMANISHI \\ Department of Polymer Chemistry, Kyoto University, \\ Yoshida, Sakyo-ku, Kyoto 606, Japan
}

(Received April 6, 1982)

\begin{abstract}
KEY WORDS Cyclo(D- or L-Leu-L-His) / Charged Carboxylic Acid Ester / Hydrophobic Interaction / Hydrolytic Reaction /
\end{abstract}

The special arrangement of functional groups and their cooperative interactions constitute an essential part of the molecular mechanism of enzyme reactions. Cyclic peptides carrying functional groups fixed at specific positions along the molecular skeleton are suitable model compounds for enzymes in studying the structure - catalytic activity relationship. The specific arrangement of the functional groups in cyclic peptides can be determined by NMR and CD spectroscopy.

In our previous studies, two cyclic dipeptides carrying nucleophilic groups, i.e., cyclo(D-Leu-LHis) and cyclo(D-Val-L-His), were found to show specific and effective catalyses for the hydrolyses of hydrophobic active esters, i.e., $p$-nitrophenyl esters of lauric acid $\left[\mathrm{CH}_{3}\left(\mathrm{CH}_{2}\right)_{10} \mathrm{COOPh}\left(\mathrm{NO}_{2}\right)\right]$ and decanoic acid $\left[\mathrm{CH}_{3}\left(\mathrm{CH}_{2}\right)_{8} \mathrm{COOPh}\left(\mathrm{NO}_{2}\right)\right]^{1,2}$ Conformational analysis of the cyclic dipeptides mainly by NMR indicated the catalytic effectiveness to be controlled by the substrate binding due to hydrophobic interactions and the stereochemical fit of functional groups in the peptide-substrate complex to enhance the intramolecular nucleophilic attack. ${ }^{2,3}$

In order to design an effective catalyst on the basis of a hydrophobic interaction the hydrophobicities of the catalyst and the substrate should be maximized. However, an increase in the hydrophobicity of the substances simultaneously decreases their solubility in water, resulting in a complexity due to molecular associations. ${ }^{2}$ In the present study, active esters with long hydrocarbon chains and positive or negative charges were prepared and subjected to catalytic hydrolysis using hydrophobic cyclic peptides. These substrates were expected to be hydrophobic but still have good solubility in water.

\section{EXPERIMENTAL}

\section{Catalysts}

Imidazole was used as a standard nucleophile. It was obtained from a commercial source and purified by recrystallization from benzene.

As cyclic dipeptides carrying hydrophobic and nucleophilic side chains, cyclo(D- or L-Leu-L-His) ${ }^{1,2}$ and cyclo(D-Ala-L-His) ${ }^{2}$ were used. The synthesis of these cyclic dipeptides have been reported previously.

\section{Substrates}

p-Nitrophenyl esters of acetic acid $\left[\mathrm{CH}_{3} \mathrm{COO}\right.$ $\left.\mathrm{Ph}\left(\mathrm{NO}_{2}\right)\right]$ and lauric acid $\left[\mathrm{CH}_{3}\left(\mathrm{CH}_{2}\right)_{10} \mathrm{COOPh}\right.$ $\left(\mathrm{NO}_{2}\right)$ ] were used as non-ionic substrates. The synthesis and purification of these compounds have been described. ${ }^{1}$

As carboxylic acid esters carrying a negative charge, 3-acyloxy-4-nitrobenzoic acids $\left(\mathrm{S}_{n}^{-}, n=2\right.$, 10,12 , and 18) were prepared, where $n$ is the number of carbon atoms in the acyloxy group. They were synthesized in a manner similar to that reported by Overberger, et al. ${ }^{4,5}$ 3-Acetoxy-4-nitrobenzoic acid $\left(\mathrm{S}_{2}^{-}\right)$was recrystallized from methanol; $\mathrm{mp} 182^{\circ} \mathrm{C}$. Anal. Calcd for $\mathrm{C}_{9} \mathrm{H}_{7} \mathrm{NO}_{6}$ : C, $48.01 \%$; H, $3.13 \%$; N, $6.22 \%$. Found: C, $47.78 \%$; H, $2.87 \% ; \mathrm{N}, 6.02 \%$.

3-Decanoyloxy-4-nitrobenzoic acid $\left(\mathrm{S}_{10}^{-}\right)$was purified by recrystallization from methanol; $\mathrm{mp}$ $139^{\circ} \mathrm{C}$. Anal. Calcd for $\mathrm{C}_{17} \mathrm{H}_{23} \mathrm{NO}_{6} ; \mathrm{C}, 60.52 \% ; \mathrm{H}$, 
$6.87 \%$; N, $4.15 \%$. Found: C, $60.55 \% ; \mathrm{H}, 6.78 \%$; N, $4.23 \%$.

3-Dodecanoyloxy-4-nitrobenzoic acid $\left(\mathrm{S}_{12}^{-}\right)$was recrystallized from methanol; $\mathrm{mp} 142-145^{\circ} \mathrm{C}$. Anal. Calcd for $\mathrm{C}_{19} \mathrm{H}_{27} \mathrm{NO}_{6}: \mathrm{C}, 62.50 \% ; \mathrm{H}, 7.47 \%$; N, $3.84 \%$. Found: C, $62.25 \%$; H, $7.47 \%$; N, 3.87\%.

3-Stearoyloxy-4-nitrobenzoic acid $\left(\mathrm{S}_{18}^{-}\right)$was recrystallized from ethanol; mp $138-140^{\circ} \mathrm{C}$. Anal. Calcd for $\mathrm{C}_{25} \mathrm{H}_{39} \mathrm{NO}_{6}: \mathrm{C}, 66.77 \% ; \mathrm{H}, 8.76 \% ; \mathrm{N}$, $3.12 \%$. Found: C, $66.55 \%$; H, $8.37 \%$; N, $3.12 \%$.

Carboxylic acid esters with a positive charge, 3acyloxy- $N$-trimethylanilinium iodide $\left(\mathrm{S}_{n}^{+}, n=2,6\right.$, 10 , and 12) were also synthesized. The suffix $n$ again indicates the number of carbon atoms in the acyloxy group. A preparative method reported by Overberger, et al. ${ }^{4,6}$ was followed. 3-Acetoxy- $N$ trimethylanilinium iodide $\left(\mathrm{S}_{2}^{+}\right)$was recrystallized from methanol; mp $211-212^{\circ} \mathrm{C}$. (lit. ${ }^{4} 209-210^{\circ} \mathrm{C}$ ). Anal. Calcd for $\mathrm{C}_{11} \mathrm{H}_{16} \mathrm{NO}_{2} \mathrm{I}: \mathrm{C}, 41.14 \% ; \mathrm{H}, 5.02 \%$; N, $4.36 \%$; I, $39.51 \%$. Found: C, $41.02 \%$; H, $4.87 \%$; $\mathrm{N}, 4.23 \%$; I, 39.37\%

3-Hexanoyloxy- $N$-trimethylanilinium iodide $\left(\mathrm{S}_{6}^{+}\right)$ was recrystallized from methanol; mp $122^{\circ} \mathrm{C}$. Anal. Calcd for $\mathrm{C}_{15} \mathrm{H}_{24} \mathrm{NO}_{2} \mathrm{I}: \mathrm{C}, 47.76 \% ; \mathrm{H}, 6.41 \%$; N, $3.71 \%$; I, 33.64\%. Found: C, 48.04\%; H, 6.43\%; N, $3.85 \%$; I, $33.87 \%$.

3-Decanoyloxy- $N$-trimethylanilinium iodide $\left(\mathrm{S}_{10}^{+}\right)$ was recrystallized from 2-propanol; mp 131$132^{\circ}$ C. Anal. Calcd for $\mathrm{C}_{19} \mathrm{H}_{32} \mathrm{NO}_{2} \mathrm{I}: \mathrm{C}, 52.66 \%$; $\mathrm{H}$, $7.44 \%$; N, $3.23 \%$; I, $29.28 \%$. Found: C, $52.83 \%$; H, $7.31 \%$; N, 3.38\%; I, $29.32 \%$.

3-Dodecanoyloxy- $N$-trimethylanilinium iodide $\left(\mathrm{S}_{12}^{+}\right)$was recrystallized from 2-propanol; $\mathrm{mp} 130$ $131.5^{\circ} \mathrm{C}$ [lit. ${ }^{6} \mathrm{mp} 121-121.5^{\circ} \mathrm{C}$ (dec.)]. Anal. Calcd for $\mathrm{C}_{21} \mathrm{H}_{36} \mathrm{NO}_{2} \mathrm{I}$ : C, $54.65 \% ; \mathrm{H}, 7.88 \% ; \mathrm{N}, 3.04 \%$; I, $27.50 \%$; Found: C, $54.40 \%$; H, $7.82 \%$; N, $2.85 \%$; I, $27.69 \%$.

$\omega$-Aminododecanoic acid $p$-nitrophenyl ester hydrochloride $\left[\mathrm{Cl}^{-} \mathrm{H}_{3} \mathrm{~N}^{+}\left(\mathrm{CH}_{2}\right)_{11} \mathrm{COOPh}\left(\mathrm{NO}_{2}\right)\right]$ was prepared from $\omega$-aminododecanoic acid. The amino group of the latter was first protected by the $t$-butyloxycarbonyl group and the acid was converted to the $p$-nitrophenyl ester by the dicyclohexylcarbodiimide method. The amino-protecting group was removed by treatment with $\mathrm{HCl}$ /dioxane and the ester was recrystallized from methanol; mp $153^{\circ} \mathrm{C}$. Anal. Calcd for $\mathrm{C}_{18} \mathrm{H}_{29} \mathrm{~N}_{2} \mathrm{O}_{4} \mathrm{Cl}$ : C, $57.98 \%$; H, 7.84\%; N, 7.51\%. Found: C, $57.97 \%$; $\mathrm{H}, 7.91 \%$; N $7.47 \%$.

$p$-Nitrophenyl glycinate hydrochloride [Gly-
$\left.\mathrm{OPh}\left(\mathrm{NO}_{2}\right) \cdot \mathrm{HCl}\right], p$-nitrophenyl L- or D-valinate hydrochloride [L- or $\mathrm{D}-\mathrm{Val}-\mathrm{OPh}\left(\mathrm{NO}_{2}\right) \cdot \mathrm{HCl}$, and $p$ nitrophenyl L- or D-leucinate hydrochloride [L or DLeu-OPh $\left(\mathrm{NO}_{2}\right) \cdot \mathrm{HCl}$ ] were synthesized by the condensation of $p$-nitrophenol with the respective $N$ - $t$ butyloxycarbonyl- $\alpha$-amino acids using dicyclohexylcarbodiimide and subsequent deblocking of the $N$-protecting group with $\mathrm{HCl} /$ dioxane. The products were purified by recrystallization and identified by IR spectroscopy and TLC. Gly$\mathrm{OPh}\left(\mathrm{NO}_{2}\right) \cdot \mathrm{HCl}$ was recrystallized from ethanol/ methanol; $\mathrm{mp} 183^{\circ} \mathrm{C}$. Anal. Calcd for $\mathrm{C}_{8} \mathrm{H}_{9} \mathrm{~N}_{2} \mathrm{O}_{4} \mathrm{Cl}$ : $\mathrm{C}, 41.31 \% ; \mathrm{H}, 3.90 \%$; N, $12.04 \%$. Found: C, $41.33 \%$; H, 3.93\%; N, $12.01 \%$.

$\mathrm{L}-\mathrm{Val}-\mathrm{OPh}\left(\mathrm{NO}_{2}\right) \cdot \mathrm{HCl}$ was recrystallized from ethanol; $\mathrm{mp} 176^{\circ} \mathrm{C}$. Anal. Calcd for $\mathrm{C}_{11} \mathrm{H}_{15} \mathrm{~N}_{2} \mathrm{O}_{4} \mathrm{Cl}$ : $\mathrm{C}, 48.10 \% ; \mathrm{H}, 5.50 \% ; \mathrm{N}, 10.20 \%$. Found: $\mathrm{C}$, $48.25 \%$; H, $5.55 \%$; N, $10.11 \%$.

$\mathrm{D}-\mathrm{Val}-\mathrm{OPh}\left(\mathrm{NO}_{2}\right) \cdot \mathrm{HCl}$ was recrystallized from ethanol; mp $178^{\circ} \mathrm{C}$. Anal. Found: C, $48.39 \%$; H, $5.51 \% ; \mathrm{N}, 10.24 \%$.

L-Leu-OPh$\left(\mathrm{NO}_{2}\right) \cdot \mathrm{HCl}$ was recrystallized from ethanol: $\mathrm{mp} 173^{\circ} \mathrm{C}$. Anal. Calcd for $\mathrm{C}_{12} \mathrm{H}_{17} \mathrm{~N}_{2} \mathrm{O}_{4} \mathrm{Cl}$ : C, $49.92 \%$; H, 5.94\%; N, 9.70\%. Found: C, $50.02 \%$; $\mathrm{H}, 5.94 \% ; \mathrm{N}, 9.72 \%$.

D-Leu-OPh $\left(\mathrm{NO}_{2}\right) \cdot \mathrm{HCl}$ was recrystallized from ethanol; mp $174^{\circ} \mathrm{C}$. Anal. Found: C, $49.86 \%$, H, $5.92 \% ; \mathrm{N}, 9.71 \%$.

\section{Catalytic Hydrolysis}

Catalytic hydrolyses of the above substrates were carried out under various conditions and are described in detail with the respective experimental results. The hydrolyses of substrates other than $\alpha$ amino acid ester hydrochlorides by the peptide catalysts were performed at pH $7.8\left(\mathrm{KH}_{2} \mathrm{PO}_{4}^{-}\right.$ $\mathrm{NaOH}$ buffer) and $25^{\circ} \mathrm{C}$. Hydrolyses of $\mathrm{S}_{n}^{+}, \mathrm{S}_{n}^{-}$, and non-ionic esters were carried out in ethanol/water mixed solvents. A stock solution of the substrate was prepared in ethanol and kept in a thermostatted bath. The hydrolysis was started by adding an aliquot of the substrate solution to a mixture of a buffer and catalyst solutions in the same thermostatted bath. In the case of

$$
\mathrm{Cl}^{-} \mathrm{H}_{3} \mathrm{~N}^{+}\left(\mathrm{CH}_{2}\right)_{11} \mathrm{COOPh}\left(\mathrm{NO}_{2}\right) \text {, }
$$

the stock solution was made with $1 / 100 \mathrm{~N}$ hydrochloric acid containing ethanol. The hydrolysis was followed by an increase in phenolate anion absorption at $278 \mathrm{~nm}$ for $\mathrm{S}_{n}^{+}, 428 \mathrm{~nm}$ for $\mathrm{S}_{n}^{-}$, and 
$400 \mathrm{~nm}$ for other substrates. The second-order rate constant $k_{\text {cat }}$ was calculated on the basis of the concentration of the effective catalyst as reported before. ${ }^{1,2}$

Hydrolyses of $\alpha$-amino acid ester hydrochlorides by the peptide catalysts were carried out at $25^{\circ} \mathrm{C}$ and $\mathrm{pH} 6.95\left(\mathrm{KH}_{2} \mathrm{PO}_{4}-\mathrm{NaOH}\right.$ buffer $)$ in aqueous solutions. A mixture of the buffer solution and the aqueous catalyst solution was kept at a constant temperature in an optical cell, and a N/100 hydrochloric acid solution of the substrate maintained at the same temperature, was added so as to start the hydrolytic reaction. The substrate concentration

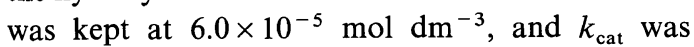
determined by the same method as above. At $\mathrm{pH}$ 6.95 , the effective concentrations of the cyclic peptides and imidazole were different from the bulk concentrations, and the corrections of $k_{\text {cat }}$ were made on the basis of the fraction of the neutral imidazole function $\alpha$. At $\mathrm{pH}$ 6.95, the $\alpha$ values of imidazole, cyclo(D-Leu-L-His), and cyclo(L-Leu-L-
His) were $0.44,0.90$, and 0.84 , respectively.

\section{RESULTS}

\section{Hydrolyses of Negatively Charged Substrates}

In $20 \%$ dioxane/water mixed solvents, the specific and efficient catalyses by cyclo(D-Leu-L-His) ${ }^{1,2}$ and cyclo(D-Val-L-His) ${ }^{2}$ in the hydrolyses of two longchain carboxylic acid esters such as $\mathrm{CH}_{3}\left(\mathrm{CH}_{2}\right)_{10^{-}}$ $\operatorname{COOPh}\left(\mathrm{NO}_{2}\right)$ and $\mathrm{CH}_{3}\left(\mathrm{CH}_{2}\right)_{8} \mathrm{COOPh}\left(\mathrm{NO}_{2}\right)$ have been reported. The $k_{\text {cat }}$ values observed in these cases exceeded that of imidazole which had a higher basicity than the cyclic dipeptides. Though the effect was not very marked, the hydrophobic interaction between the catalyst and the substrate, and the stereochemical fit between them to make possible cooperation of functional groups in intramolecular nucleophilic catalysis have been found essential for the efficiency. As far as the chain length of the acyl group in a substrate is concerned, long-chain carboxylic acid esters such as $\mathrm{S}_{12}^{-}$and

Table I. Second-order rate constants $\left(k_{\text {cat }}, \mathrm{dm}^{3} \mathrm{~mol}^{-1} \mathrm{~min}^{-1}\right)$ for the hydrolysis of 3-acyloxy-4-nitrobenzoic acid $\left(\mathrm{S}_{n}^{-}\right)^{\mathrm{a}}$

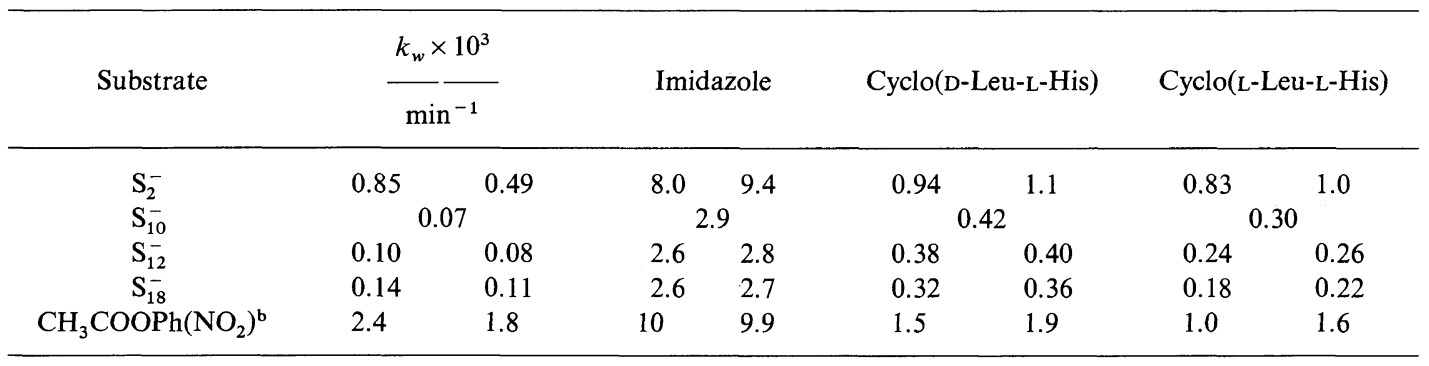

a $25^{\circ} \mathrm{C}, \mathrm{pH} 7.8,40 \% \mathrm{EtOH} / \mathrm{H}_{2} \mathrm{O},\left[\mathrm{S}_{n}^{-}\right]=6.0 \times 10^{-5} \mathrm{moldm}^{-3}$, [Catalyst] $=4.5-5.5 \times 10^{-4} \mathrm{~mol} \mathrm{dm}^{-3}$.

b $\left[\mathrm{CH}_{3} \mathrm{COOPh}\left(\mathrm{NO}_{2}\right)\right]=3.0 \times 10^{-5} \mathrm{~mol} \mathrm{dm}^{-3}$.

Table II. Second-order rate constants $\left(k_{\text {cat }}, \mathrm{dm}^{3} \mathrm{~mol}^{-1} \mathrm{~min}^{-1}\right)$ for the hydrolysis of 3-acyloxy-4-nitrobenzoic acid $\left(\mathrm{S}_{n}^{-}\right)^{\mathbf{a}}$

\begin{tabular}{|c|c|c|c|c|c|}
\hline \multirow{2}{*}{ Substrate } & \multicolumn{2}{|c|}{$k_{w} \times 10^{3}$} & \multirow{2}{*}{ Imidazole } & \multirow{2}{*}{ Cyclo(D-Leu-L-His) } & \multirow{2}{*}{ Cyclo(D-Ala-L-His) } \\
\hline & & & & & \\
\hline $\mathrm{S}_{2}^{-}$ & \multicolumn{2}{|c|}{0.62} & 17 & 1.9 & - \\
\hline $\mathrm{S}_{10}^{-}$ & \multicolumn{2}{|c|}{0.13} & 5.8 & 0.74 & - \\
\hline $\mathrm{S}_{12}^{-}$ & \multicolumn{2}{|c|}{0.11} & 5.5 & 0.80 & 0.54 \\
\hline $\mathrm{S}_{18}^{-}$ & 0.38 & 0.40 & $6.6 \quad 7.6$ & 0.66 & 0.45 \\
\hline $\mathrm{CH}_{3} \mathrm{COOPh}\left(\mathrm{NO}_{2}\right)^{\mathbf{b}}$ & \multicolumn{2}{|c|}{1.9} & 15 & 2.7 & - \\
\hline
\end{tabular}

a $25^{\circ} \mathrm{C}, \mathrm{pH} 7.8,33 \% \mathrm{EtOH} / \mathrm{H}_{2} \mathrm{O},\left[\mathrm{S}_{n}^{-}\right]=6.0 \times 10^{-5} \mathrm{~mol} \mathrm{dm}{ }^{-3}$, [Catalyst] $=5.0-6.0 \times 10^{-4} \mathrm{~mol} \mathrm{dm}^{-3}$.

b $\left[\mathrm{CH}_{3} \mathrm{COOPh}\left(\mathrm{NO}_{2}\right)\right]=3.0 \times 10^{-5} \mathrm{~mol} \mathrm{dm}^{-3}$. 
$\mathrm{S}_{18}^{-}$are very hydrophobic and thus were expected to be hydrolyzed more efficiently by cyclo(D-LeuL-His) than by cyclo(D-Ala-L-His) or imidazole.

Hydrolyses of a series of carboxylic acid active esters each having a negative charge on its alcoholic part were carried out using hydrophobic dipeptides carrying nucleophilic groups. The results for this are presented in Table I. The rate constant $k_{\text {cat }}$ of $\mathrm{CH}_{3} \mathrm{COOPh}\left(\mathrm{NO}_{2}\right)$ is also shown for comparison. Two values in the same column indicate the results from two independent runs to show the reproducibility of the data. It is seen that the above expectation could not be realized in the present case as far as the data in Table I are concerned.

The hydrolytic reactions of the same substrates were carried out in $33.3 \% \mathrm{EtOH} / \mathrm{H}_{2} \mathrm{O}$ mixed solvents and different catalysts were compared. The results of the hydrolyses are shown in Table II. Neither the change in solvent composition nor the change in the alkyl side chain of cyclic peptides caused a significant change in $k_{\text {cat }}$. These results indicate that there is no particular interaction between the catalysts and the substrates under the conditions of Tables I and II.

\section{Hydrolyses of Positively Charged Substrates}

Catalytic hydrolyses of a series of carboxylic acid active esters having a positive charge on the alcoholic part and those having a positive charge at the terminal of the acryl chain were carried out by the nucleophilic and hydrophobic cyclic dipeptides. To examine the stereochemical fit between the functional groups in the catalysts and the substrates, a diastereomeric pair of catalysts, cyclo(DLeu-L-His) and cyclo(L-Leu-L-His), were compared. The results are listed in Table III.

As evident from the table, cyclo(L- or D-Leu-LHis) shows no marked catalytic activity toward $\mathrm{S}_{10}^{+}$ even in a solvent of high water content. A slight increase in the catalytic activity in $9.1 \% \mathrm{EtOH} / \mathrm{H}_{2} \mathrm{O}$ from that in $20 \% \mathrm{EtOH} / \mathrm{H}_{2} \mathrm{O}$ may have resulted from increased polarity of the solvent.

$\mathrm{S}_{n}^{+}$and $\mathrm{S}_{n}^{-}$have their positive or negative charge on the alcoholic parts, whereas the positive charge of $\mathrm{Cl}^{-} \mathrm{H}_{3} \mathrm{~N}^{+}\left(\mathrm{CH}_{2}\right)_{11} \mathrm{COOPh}\left(\mathrm{NO}_{2}\right)$ is located at the end of the acyl chain. Similarly, the activity of cyclo(L- or D-Leu-L-His) toward

$$
\mathrm{Cl}^{-} \mathrm{H}_{3} \mathrm{~N}^{+}\left(\mathrm{CH}_{2}\right)_{11} \mathrm{COOPh}\left(\mathrm{NO}_{2}\right)
$$

was not very high.

Cyclo(D-Leu-L-His) showed a higher catalytic activity than cyclo(L-Leu-L-His) by an approximate factor of two for all substrates examined. This may not necessarily indicate the stereochemical fit of the functional groups but a smaller steric hindrance involved in the nucleophilic attack of the imidazolyl group of cyclo(D-Leu-L-His) than cyclo(L-Leu-LHis). In cyclo(D-Leu-L-His), the bulky isobutyl group and the imidazolyl group are on the opposite side of the diketopiperazine ring.

\section{Hydrolyses of Hydrophobic $\alpha$-Amino Acid Active Ester Hydrochlorides \\ Cationically charged active esters of $\alpha$-amino}

Table III. Second-order rate constants $\left(k_{\text {cat }}, \mathrm{dm}^{3} \mathrm{~mol}^{-1} \min ^{-1}\right)$ for the hydrolysis of 3-acyloxy- $N$-trimethylanilinium iodide $\left(\mathrm{S}_{n}^{+}\right)$and $p$-nitrophenyl $\omega$-aminododecanoate hydrochloride

\begin{tabular}{|c|c|c|c|c|c|}
\hline Substrate & Solvent & $\frac{k_{w} \times 10^{3}}{\min ^{-1}}$ & Imidazole & $\begin{array}{c}\text { Cyclo(D-Leu- } \\
\text { L-His) }\end{array}$ & $\begin{array}{c}\text { Cyclo(L-Leu- } \\
\text { L-His) }\end{array}$ \\
\hline $\mathrm{S}_{2}^{+}$ & $20 \% \mathrm{EtOH} / \mathrm{H}_{2} \mathrm{O}^{\mathrm{a}}$ & 1.6 & 7.5 & 0.45 & - \\
\hline $\mathrm{S}_{6}^{+}$ & $20 \% \mathrm{EtOH} / \mathrm{H}_{2} \mathrm{O}^{\mathrm{a}}$ & 0.68 & 4.7 & 0.50 & - \\
\hline $\mathrm{S}_{10}^{+}$ & $20 \% \mathrm{EtOH} / \mathrm{H}_{2} \mathrm{O}^{\mathrm{a}}$ & 0.61 & 4.3 & 0.52 & - \\
\hline $\mathrm{S}_{2}^{+}$ & $9.1 \% \mathrm{EtOH} / \mathrm{H}_{2} \mathrm{O}^{\mathrm{b}}$ & 1.0 & 9.6 & 0.90 & 0.49 \\
\hline $\mathrm{S}_{6}^{+}$ & $9.1 \% \mathrm{EtOH} / \mathrm{H}_{2} \mathrm{O}^{\mathrm{b}}$ & 0.48 & 5.4 & 0.76 & 0.36 \\
\hline $\mathrm{S}_{10}^{+}$ & $9.1 \% \mathrm{EtOH} / \mathrm{H}_{2} \mathrm{O}^{\mathrm{b}}$ & 0.54 & 6.7 & 0.88 & 0.41 \\
\hline $\mathrm{Cl}^{-} \mathrm{H}_{3} \mathrm{~N}^{+}\left(\mathrm{CH}_{2}\right)_{11} \mathrm{COOPh}\left(\mathrm{NO}_{2}\right)$ & $6.65 \% \mathrm{MeOH} / \mathrm{H}_{2} \mathrm{O}^{\mathrm{c}}$ & 1.2 & 13 & 2.8 & 1.4 \\
\hline
\end{tabular}

a $25^{\circ} \mathrm{C}, \mathrm{pH} 7.8,\left[\mathrm{~S}_{n}^{+}\right]=1.8 \times 10^{-4} \mathrm{~mol} \mathrm{dm}^{-3},[$ Catalyst $]=4.2-5.5 \times 10^{-4} \mathrm{~mol} \mathrm{dm}^{-3}$.

b $25^{\circ} \mathrm{C}, \mathrm{pH} 7.8,\left[\mathrm{~S}_{n}^{+}\right]=1.8 \times 10^{-4} \mathrm{~mol} \mathrm{dm}^{-3}$, [Catalyst] $=3.8-7.2 \times 10^{-4} \mathrm{~mol} \mathrm{dm}^{-3}$.

c $25^{\circ} \mathrm{C}, \mathrm{pH} 7.8,\left[\mathrm{Cl}^{-} \mathrm{H}_{3} \mathrm{~N}^{+}\left(\mathrm{CH}_{2}\right)_{11} \mathrm{COOPh}\left(\mathrm{NO}_{2}\right)\right]=3.0 \times 10^{-5} \mathrm{~mol} \mathrm{dm}^{-3}$, [Catalyst] $=6.7-12 \times 10^{-4} \mathrm{~mol} \mathrm{dm}^{-3}$. 
Table IV. Second-order rate constants $\left(k_{\text {cat }}, \mathrm{dm}^{3} \mathrm{~mol}^{-1} \mathrm{~s}^{-1}\right)$ for the hydrolysis of $\alpha$-amino acid $p$-nitrophenyl ester hydrochlorides ${ }^{\mathbf{a}}$

\begin{tabular}{|c|c|c|c|c|c|}
\hline \multirow{2}{*}{ Catalyst } & \multirow{2}{*}{$\mathrm{Gly}-\mathrm{OPh}\left(\mathrm{NO}_{2}\right) \cdot \mathrm{HCl}$} & \multicolumn{2}{|c|}{ Val-OPh $\left(\mathrm{NO}_{2}\right) \cdot \mathrm{HCl}$} & \multicolumn{2}{|c|}{ Leu-OPh$\left(\mathrm{NO}_{2}\right) \cdot \mathrm{HCl}$} \\
\hline & & $\mathbf{L}$ & $\mathrm{D}$ & $\mathbf{L}$ & D \\
\hline None $\left(k_{w} \times 10^{3}, \mathrm{~s}^{-1}\right)$ & 5.60 & 3.15 & 3.30 & 4.75 & 4.93 \\
\hline Imidazole & $4.1(9.3)$ & $0.6(1.4)$ & $0.5(1.1)$ & $3.5(8.0)$ & $3.2(7.3)$ \\
\hline Cyclo(L-Leu-L-His) & $2.8(3.3)$ & $2.4(2.8)$ & $2.2(2.6)$ & $2.9(3.5)$ & $2.6(3.1)$ \\
\hline Cyclo(D-Leu-L-His) & $4.9(5.4)$ & $5.8(6.4)$ & $5.2(5.8)$ & $5.2(5.8)$ & $4.4(4.9)$ \\
\hline
\end{tabular}

a $25^{\circ} \mathrm{C}, \mathrm{pH} 6.95$, aqueous solution, [Substrate] $=6.0 \times 10^{-5} \mathrm{~mol} \mathrm{dm}^{-3} . k_{\text {cat }}$ values given in parentheses are those corrected for the fraction of neutral imidazole functions.

acids carrying a hydrophobic alkyl side chain such as leucine and valine are highly soluble in water and the hydrolytic behavior can be investigated with a high substrate concentration in an aqueous solution. The contribution of the hydrophobic interaction may easily be detected and an asymmetric hydrolysis may possibly occur. The experimental results obtained with $\mathrm{Val}-\mathrm{OPh}\left(\mathrm{NO}_{2}\right) \cdot \mathrm{HCl}$ and Leu$\mathrm{OPh}\left(\mathrm{NO}_{2}\right) \cdot \mathrm{HCl}$ are summarized in Table IV.

It should be stressed that in these hydrolytic reactions, the cyclic dipeptide catalysts were nearly as effective as or more so than imidazole, although the former are less basic than the latter. Since imidazole is more basic and consequently the fraction $\alpha$ of the catalytically active, neutral imidazole function is low under the experimental conditions (pH 6.95), the correction of $k_{\text {cat }}$ was made for $\alpha$ with the catalysts concerned. In the hydrolysis of Val$\mathrm{OPh}\left(\mathrm{NO}_{2}\right) \cdot \mathrm{HCl}$, cyclic dipeptides were still more efficient catalysts than imidazole. As in other cases, cyclo(D-Leu-L-His) was more effective than cyclo(LLeu-L-His) under the present conditions. The higher catalytic activity of cyclo(D-Leu-L-His) may possibly be due to a smaller degree of steric hindrance in the intramolecular catalysis by the imidazolyl group toward a bound substrate. No evidence for an asymmetric catalysis was found in the present system.

\section{DISCUSSION}

Cyclo(L- or D-Leu-L-His) was not a particularly effective catalyst for the solvolyses of charged, longchain carboxylic acid esters in aqueous alcohol solutions containing a high proportion of water. This indicates that special interactions did not occur between the catalysts and the substrates under the present conditions. As reported previously, ${ }^{1,2}$ cyclo(D-Leu-L-His) and cyclo(D-Val-L-His) were efficient catalysts in the hydrolyses of neutral, longchain carboxylic acid $p$-nitrophenyl esters due to the hydrophobic interaction. That the same cyclic dipeptides were inactive in the solvolyses of charged substrates should indicate that the hydrophobic interaction was weakened by the charge of the substrate. However, the experimental finding that cyclo(D-Leu-L-His) was more efficient than imidazole in the hydrolysis of valine $p$-nitrophenyl ester hydrochloride should indicate the involvement of a hydrophobic interaction between the catalyst and the substrate. It should be remembered that the hydrolyses of $\alpha$-amino acid $p$-nitrophenyl ester hydrochlorides by imidazole derivatives proceed possibly by the general-base catalysis, ${ }^{7}$ while the usual esterolytic action of imidazole derivatives is nucleophilic. The alteration of the catalytic mechanism should have led to a stereochemical fit between a bound substrate and a catalytic group.

Overberger and Podsiadly ${ }^{6}$ have reported the enhanced hydrolyses of cationically charged, longchain carboxylic acid esters by the copolymers of 5(6)-vinylbenzimidazole and acrylic acid due to the hydrophobic interactions. In order to bind charged substrates by hydrophobic interactions, a hydrophobic domain should be formed along a flexible polymer chain. In the present investigation, an asymmetric hydrolysis of an $\alpha$-amino acid ester hydrochloride was not possible by the chiral cyclic dipeptide catalysts. To construct an asymmetric catalyst, a strict stereochemical control would be necessary either in the substrate binding or in the subsequent intramolecular catalysis. From both 


\section{K. KaWaguchi, M. TANihara, and Y. Imanishi}

points of view, large-membered, multi-functional cyclic peptides are expected to be highly efficient asymmetric catalysts.

\section{REFERENCES}

1. Y. Imanishi, M. Tanihara, T. Sugihara, and T. Higashimura, Biopolymers, 16, 2203 (1977).

2. Y. Masuda, M. Tanihara, Y. Imanishi, and T. Higashimura, Biopolymers, submitted.
3. M. Tanihara, Y. Imanishi, and T. Higashimura, Biopolymers, 16, 2217 (1977).

4. C. G. Overberger, J. C. Salamone, and S. Yaroslavsky, J. Am. Chem. Soc., 89, 6231 (1967).

5. C. G. Overberger and C. J. Podsiadly, Bioorg. Chem., 3, 16 (1974).

6. C. G. Overberger and C. J. Podsiadly, Bioorg. Chem., 3, 35 (1974).

7. M. Tanihara and Y. Imanishi, Int. J. Biol. Macromol., 4, 194 (1982). 